\title{
1 Mercury toxicity in livers of northern pike (Esox lucius) from Isle Royale, USA
}

3 Paul E. Drevnick ${ }^{\mathrm{a},}$, , Aaron P. Roberts ${ }^{\mathrm{b}}$, Ryan R. Otter ${ }^{\mathrm{a}}$, Chad R. Hammerschmidt ${ }^{\mathrm{c}}$, Rebecca

4 Klaper $^{\mathrm{d}}$, James T. Oris ${ }^{\mathrm{a}}$

$6 \quad{ }^{a}$ Department of Zoology, Miami University, Oxford, OH 45056, USA

$7 \quad{ }^{b}$ Department of Biological Sciences, University of North Texas, Denton, TX 76203, USA

$8{ }^{c}$ Department of Marine Chemistry \& Geochemistry, Woods Hole Oceanographic Institution,

9 Woods Hole, MA 02543, USA

10 dGreat Lakes WATER Institute, University of Wisconsin-Milwaukee, 600 East Greenfield

11 Avenue, Milwaukee, WI 53204, USA

12

$13{ }^{*}$ Corresponding author.

14 Present address: Department of Marine Chemistry \& Geochemistry, Woods Hole Oceanographic

15 Institution, Woods Hole, MA 02543, USA. Tel. +1 508 289 3551; fax +1 5084572075.

16 E-mail address: pdrevnick@whoi.edu. 


\section{Abstract}

Many laboratory studies have documented that mercury can be toxic to fish, but it is

20 largely unknown if mercury is toxic to fish in their natural environments. The objective of our

21 study was to investigate the toxic effects of mercury on northern pike (Esox lucius) at Isle

22 Royale, Michigan. In 124 northern pike from eight inland lakes, concentrations of total mercury

23 in skin-on fillets ranged from 0.069 to $0.622 \mu \mathrm{g} / \mathrm{g}$ wet wt. Concentrations of total mercury in

24 livers increased exponentially compared with concentrations in fillets, to a maximum of $3.1 \mu \mathrm{g} / \mathrm{g}$

25 wet wt. Methylmercury constituted a majority of the mercury in livers with total mercury

26 concentrations $<0.5 \mu \mathrm{g} / \mathrm{g}$ wet wt, but declined to $28-51 \%$ of the mercury in livers with total

27 mercury concentrations $>0.5 \mu \mathrm{g} / \mathrm{g}$ wet wt. Liver color (absorbance at $400 \mathrm{~nm}$ ) varied among

28 northern pike and was positively related to liver total mercury concentration. The pigment

29 causing variation in liver color was identified as lipofuscin, which results from lipid peroxidation

30 of membranous organelles. An analysis of covariance revealed lipofuscin accumulation was

31 primarily associated with mercury exposure, and this association obscured any normal

32 accumulation from aging. We also documented decreased lipid reserves in livers and poor

33 condition factors of northern pike with high liver total mercury concentrations. Our results

34 suggest (i) northern pike at Isle Royale are experiencing toxicity at concentrations of total

35 mercury common for northern pike and other piscivorous fish elsewhere in North America and

36 (ii) liver color may be useful for indicating mercury exposure and effects in northern pike at Isle

37 Royale and possibly other aquatic ecosystems and other fish species.

39 Keywords: mercury, methylmercury, northern pike, liver, lipofuscin 


\section{Introduction}

Many laboratory studies have documented that mercury can be toxic to fish. Early studies reported effects on survival and growth, but fish were exposed to inorganic mercury or methylmercury (MeHg) in water at unrealistically high concentrations (Wiener and Spry, 1996). It has since been discovered that nearly all mercury in wild fish is $\mathrm{MeHg}$ (Bloom, 1992), and $\mathrm{MeHg}$ is accumulated almost entirely via dietary uptake (Hall et al, 1997). There is now a growing body of evidence that suggests reproduction of fish is impaired by exposure to dietary $\mathrm{MeHg}$ at concentrations reported for many aquatic food webs in North America (e.g., Matta et al., 2001; Hammerschmidt et al., 2002; Drevnick and Sandheinrich, 2003). We have found that MeHg induces apoptosis of steroidogenic gonadal cells in fish (Drevnick et al., 2006b), resulting in suppressed sex steroid hormone levels that are linked to inhibited reproduction (Drevnick and Sandheinrich, 2003). Apoptosis is often a symptom of oxidative stress (Holden, 2000), and other recent laboratory tests have reported that dietary $\mathrm{MeHg}$ causes oxidative stress in fish (Berntssen et al., 2003; Gonzalez et al., 2005), with resultant histopathological effects in liver and other tissues (de Oliveira Ribeiro et al., 2002). It is largely unknown, however, if $\mathrm{MeHg}$ has ecosystems impacted by direct anthropogenic inputs of mercury. Toxic effects, including liver histopathology, have been associated with very high concentrations of $\mathrm{MeHg}$ in wild fish living downstream of mercury cell chlor-alkali plants (Lockhart et al., 1972; Raldúa et al., 2007). Other studies of rivers and reservoirs impacted by industry, military installations, and mining have indicated $\mathrm{MeHg}$ may alter reproductive biomarkers in wild fish, but causality is difficult to establish because of spatial and temporal variability and the presence of other contaminants

64 (Hontela et al., 1995; Meinelt et al., 1997; Adams et al., 1999; Friedmann et al., 2002; Hinck et

65 al., 2006; Webb et al., 2006). In contrast, there are few investigations of MeHg toxicity to wild 66 fish in remote aquatic systems (Wiener et al., 2007), where atmospheric deposition is the 67 principal source of mercury (Fitzgerald et al., 1998).

The objective of our study was to investigate the toxic effects of $\mathrm{MeHg}$ on a top

69 piscivorous fish species, the northern pike (Esox lucius), in lakes of Isle Royale, Michigan. Isle 
71 from atmospheric deposition (Woodruff et al, 2003). Atmospheric contaminants other than

72 mercury also are deposited to Isle Royale (e.g., organochlorines; Swackhamer and Hites, 1988),

73 but they accumulate to relatively low concentrations in northern pike (Michigan Department of

74 Environmental Quality, 2005) and are not of toxicological concern. Mercury is a concern,

75 however, because atmospherically deposited mercury is efficiently converted to $\mathrm{MeHg}$ and

76 biomagnified in aquatic food webs (Gorski et al., 2003), resulting in elevated concentrations in

77 northern pike (Kallemeyn, 2000). Levels of total mercury in skin-on fillets of northern pike,

78 nearly all of which is $\mathrm{MeHg}$ (Bloom, 1992), have recently declined at Isle Royale (Drevnick et

79 al., 2007). Even with this decline, we report elevated concentrations of total mercury and $\mathrm{MeHg}$

80 in livers of northern pike and that these mercury levels are linked to oxidative stress,

81 histopathological effects, and poor fish health. These results suggest the health of fish and their

82 ability to reproduce may be affected by concentrations of mercury common in fish across North 83 America.

\section{Materials and Methods}

\subsection{Fish sampling}

A potential link between MeHg exposure and sublethal toxic effects was examined for northern pike inhabiting eight Isle Royale lakes: Angleworm, Eva, Intermediate, Richie,

91 Sargent, Shesheeb, Siskiwit, and Wagejo. These study lakes were selected to span a broad

92 gradient of MeHg contamination, based on a survey of fish mercury levels in the mid 1990s

93 (Kallemeyn, 2000). Northern pike ( $n=124)$ were collected by gill net or hook-and-line and

94 sacrificed on site according to protocols approved by the Miami University Institutional Animal

95 Care and Use Committee. The sex of each northern pike was determined, and total length $(\mathrm{cm})$

96 and wet weight $(\mathrm{kg})$ were measured and used to calculate condition factor:

condition factor $=[100,000 \mathrm{x}$ wet weight $] /$ total length $^{3}$ techniques (Hammerschmidt et al., 1999) were used during dissection to minimize mercury 
102 contamination. At least two scales from each northern pike were examined to estimate age

103 (Jearld, 1983). Skin-on fillets and a subsample of liver were placed in individual food-grade

104 plastic bags and frozen at $-20{ }^{\circ} \mathrm{C}$. A separate subsample of liver was preserved in $10 \%$

105 phosphate-buffered formalin for histology.

\subsection{Mercury analysis}

For total mercury, skin-on fillets and livers were acid digested according to US EPA

111 atomic absorption spectroscopy (Drevnick et al., 2006a). Duplicate samples, spiked samples, 112 and certified reference materials (TORT-2, DORM-2) were digested and analyzed with each 113 batch of samples. Mean relative standard deviation for duplicate samples was 7.5\%. Recovery 114 of known additions averaged $92.8 \%$. Mean measured concentrations of reference materials were 115 within (TORT-2) or 5.5\% below (DORM-2) the certified ranges.

Ten livers were also selected for analysis of MeHg. Livers were lyophilized, digested

117 with dilute nitric acid (Hammerschmidt and Fitzgerald, 2005), and analyzed by flow-injection 118 gas chromatographic cold-vapor atomic fluorescence spectrometry (Tseng et al., 2004). Three

119 samples were analyzed in duplicate with a mean relative standard deviation of $9.6 \%$.

\subsection{Liver Toxicity}

During fish dissection, we serendipitously observed differences in liver color among

124 northern pike, and developed a method to quantitatively measure this variation. A $100 \mathrm{mg}$ piece

125 of liver was homogenized in $1 \mathrm{~mL}$ water, $0.2 \mathrm{~mL}$ chloroform were added, and the mixture was

126 centrifuged for $15 \mathrm{~min}$ at $12,000 \mathrm{rpm}$. An aliquot of the supernatant was transferred to a

127 microplate well and measured for absorbance at $400 \mathrm{~nm}$ with a spectrophotometer. It was

128 determined during methods development that $400 \mathrm{~nm}$ was the wavelength with maximum

129 absorbance for the supernatant. Each liver was analyzed in duplicate, and the results were

130 deemed acceptable if the relative standard deviation between duplicates was $<15 \%$.

131 Ten formalin-preserved livers (subsamples from the same northern pike that were 132 analyzed for $\mathrm{MeHg}$ ) were viewed for histopathology and to identify the substance that caused 
133 some livers to appear darkly colored. Livers were randomly assigned a unique random number

134 to facilitate blind study, embedded in paraffin, cut into $6 \mu \mathrm{m}$ sections, and mounted on glass

135 slides (Presnell and Schreibman, 1997). One slide from each liver was deparaffinized,

136 rehydrated, and stained with hematoxylin and eosin (Presnell and Schreibman, 1997). All slides

137 were randomly assigned to one of two staining racks and stained in the same solution batches.

138 Multiple sections on each stained slide were viewed with light microscopy at 200X

139 magnification for histopathology. An additional unstained slide from each liver was viewed with

140 fluorescence microscopy (excitation filter 355-425nm, suppression at 460nm; Woshner et al.,

1412002 ) at 200X magnification to identify lipofuscin, which from previous reports (Woshner et al.,

142 2002; Raldúa et al., 2007) we hypothesized to be the substance that caused some livers to appear 143 darkly colored.

144 Lipofuscin was quantified on a Zeiss Axio compound fluorescent microscope equipped

145 with an Axiocam High Resolution camera (Carl Zeiss Inc., Berlin, Germany). A representative

146 field of the liver of each individual was photographed at 200X, and a digital grid (squares $25 \mu \mathrm{m}$

$147 \times 25 \mu \mathrm{m}$ ) was overlaid on the digital image with Adobe Photoshop (Adobe Systems Inc., San

148 Jose, California). Fifty grid squares (out of a total of 130 per field) were selected with a random

149 number generator. Presence or absence of lipofuscin was noted and recorded in each of the

150 selected grid squares. The proportion of grid squares containing lipofuscin out of the total 50

151 assessed was used as a quantitative measure of the extent of liver damage. This process was

152 carried out on three sections for each individual, and the average score of those three sections

153 was used in the data analysis.

\subsection{Data analysis}

We analyzed data with SPSS for Windows software (version 14.0, SPSS Inc., Chicago,

159 Least-squares, stepwise multiple, and quantile regression models were used to describe

160 relationships between and among variables. Quantile regression was appropriately used for data

161 with wedge-shaped distributions (Cade and Noon, 2003). The largest quantile for which the

162 slope was statistically significant from zero $(P<0.05)$ was chosen. Analysis of covariance

163 (ANCOVA) was used to test for the effect of liver total mercury concentration on liver color, 
164 with age as a covariate. Except for stepwise multiple regression, data were transformed $\left(\log _{10}\right.$

165 transformation for liver color, total mercury concentration in fillet and liver, and liver-to-fillet

166 total mercury ratio; arcsine square root transformation for condition factor, quantitative

167 lipofuscin data, and \% MeHg of total mercury) to meet the assumptions of normality and

168 homogeneity of variance. Data were not transformed for stepwise multiple regression for ease of 169 interpretation. A type I error $(\alpha)$ of 0.05 was used to judge the significance of statistical tests.

\section{Results and Discussion}

\subsection{Total mercury and $\mathrm{MeHg}$}

Concentrations of total mercury in skin-on fillets of northern pike ranged from 0.069 to

177 fish populations and is due to a myriad of biological, chemical, and physical variables (Wiener et al., 2006). In general for lakes, fish highly contaminated with mercury ( $>1 \mu \mathrm{g} / \mathrm{g}$ wet wt total mercury in fillets) occur in systems that efficiently methylate inorganic mercury and incorporate

180 the resultant MeHg into the food web (Wiener et al., 2003). Recently at Isle Royale, reduced 181 rates of sulfate deposition have inhibited mercury methylation (Drevnick et al., 2007), and the 182 data we present for advisory lakes represent a significant decline during the past decade in total 183 mercury concentrations in skin-on fillets of northern pike. concentrations in skin-on fillets (least-squares regression, $r^{2}=0.76, P<0.001, n=124$ ), to a

187 other fish species (Goldstein et al., 1996; Cizdziel et al., 2003). Cizdziel et al. (2003) estimated

188 that the concentration of total mercury in a liver will be less than or similar to that in the fillet 189 when the concentration in the fillet is $<0.5 \mu \mathrm{g} / \mathrm{g}$ wet wt. Conversely, when the concentration of

190 total mercury in a fillet is $>0.5 \mu \mathrm{g} / \mathrm{g}$ wet wt, the concentration in the liver will be greater than that 191 of the fillet. This prediction largely holds true for our data. It is unknown, however, why this 192 exponential increase occurs. Mercury speciation may be important for understanding the cause.

193 Methylmercury constituted a majority of the mercury in livers with total mercury 194 concentrations $<0.5 \mu \mathrm{g} / \mathrm{g}$ wet wt, but declined to $28-51 \%$ of the mercury in livers with total 
195 mercury concentrations $>0.5 \mu \mathrm{g} / \mathrm{g}$ wet wt (quantile regression, $99^{\text {th }}$ quantile, $P=0.042, n=10$;

196 Fig. 1 inset). These latter values are considerably lower than the nearly $100 \% \mathrm{MeHg}$ reported for

197 fish muscle (Bloom, 1992). Low \% MeHg in liver has been reported in another study

198 (Barghigiani et al., 1989) and is hypothesized to be due to in vivo demethylation (Cizdziel et al.,

199 2003). However, fish have never been shown to be capable of demethylation (Wiener and Spry,

200 1996). Further, if demethylation were occurring in northern pike livers of this study, we would

201 expect $\mathrm{MeHg}$ concentrations in livers to be less than total mercury concentrations in skin-on

202 fillets. Instead, $\mathrm{MeHg}$ concentrations in livers are about the same or slightly greater $($ slope $=1.2)$

203 than total mercury concentrations in skin-on fillets. Rather than demethylation, we hypothesize

204 the low \% MeHg in livers is due to the accumulation of inorganic mercury from another source.

205 Fish accumulate inorganic mercury much less efficiently than MeHg (Wiener and Spry, 1996),

206 but macroinvertebrates (e.g., odonate larvae) that contain $\sim 50 \%$ of total mercury as inorganic

207 mercury (Hall et al., 1998) are a common prey item of northern pike in the lakes of Isle Royale.

208 Inorganic mercury, as well as all other substances that are digested and pass through the

209 intestinal wall, circulate first via the portal system to the liver. The liver thus has a "first pass" at

210 accumulating inorganic mercury with metal-binding proteins before it circulates to other tissues.

211 Metallothioneins (low molecular weight metal-binding proteins) have a high affinity for

212 inorganic mercury, but not MeHg (Wiener and Spry, 1996), and have been shown in wild fish to

213 be upregulated in liver in response to mercury exposure (Schlenk et al., 1995). Taken together,

214 northern pike at Isle Royale are likely exposed to sufficient amounts of inorganic mercury and

215 able to sequester in the liver what is accumulated through the gut, possibly explaining the high \%

216 inorganic mercury and low \% MeHg in livers. With age and exposure to more mercury, this

217 sequestration of "excess" inorganic mercury in the liver can also explain why there is more total

218 mercury in livers than in fillets.

\subsection{Liver Toxicity}

Liver color (absorbance at $400 \mathrm{~nm}$ ) was related positively to liver total mercury concentration (least-squares regression, $r^{2}=0.30, P<0.001, n=124$ ). Within a continuous

224 gradient, lightly-colored, pink livers (Fig. 2A) had low total mercury concentrations and darkly225 colored, red to brown livers (Fig. 2B) had high total mercury concentrations. Monitoring 
226 programs use liver color as one of many indicators of general fish health (e.g., Schmitt and

227 Dethloff, 2000), but the cause of variation in liver color among fish and its implications are often 228 unknown.

229 We identified lipofuscin as the major pigment in darkly-colored livers. Lipofuscin was 230 visible with light (Fig. 2C) and fluorescence (Fig. 2D) microscopy, and the quantitative 231 lipofuscin data (Fig. 2E) explained $81 \%$ of the variation in liver color (least-squares regression, $\left.232 r^{2}=0.81, P=0.006, n=7\right)$. Only seven of the ten livers viewed for histopathology were 233 quantified for lipofuscin because livers were overfixed, which made quantification difficult.

234 Lipofuscin is a pigment that results from lipid peroxidation (i.e., oxidative stress) of membranous 235 organelles and also is called the "pigment of aging", as it also accumulates in cells as a result of 236 age-related processes (Porta, 1989). Accordingly, ANCOVA was used to test the influence of 237 liver total mercury concentration on liver color with age as a covariate. In the ANCOVA model, 238 liver total mercury concentration still had a significant effect on liver color $\left(F_{1,107}=5.372, P=\right.$ $2390.022)$ but age did not $\left(F_{7,107}=1.758, P=0.103\right)$. Thus, the effect of mercury on lipofuscin was 240 of sufficient magnitude to obscure any normal effect of aging. Indeed, lipofuscin is usually 241 contained within cells (Porta, 1989), but livers from our study also showed lipofuscin granules 242 concentrated in some parts of the extracellular matrix. A similar pattern of lipofuscin 243 accumulation has been reported for other fish species with high concentrations of total mercury 244 in liver (Raldúa et al., 2007). These results suggest a connection between mercury exposure and 245 oxidative stress in Isle Royale northern pike.

246 We also observed a decrease in lipid reserves within hepatocytes in the livers of northern 247 pike exposed to elevated concentrations of mercury. Hepatocytes took up stain in relation to 248 lipid content. Lightly-colored livers appeared washed out after hematoxylin and eosin staining 249 and had a relative abundance of lipid vacuoles, while darkly-colored livers took up more stain 250 and had fewer lipid vacuoles. Unfortunately, however, we could not reliably quantify lipid 251 content in hepatocytes because of overfixation of livers. de Oliveira Ribeiro et al. (2002) also 252 documented a decrease in lipid reserves in livers of arctic charr (Salvelinus alpinus) exposed in 253 the laboratory to a single dose of $\mathrm{MeHg}$, but not in arctic charr exposed to a single dose of 254 dietary inorganic mercury. This suggests that the mercury toxicity we observed in Isle Royale 255 northern pike livers may be due to $\mathrm{MeHg}$ and not inorganic $\mathrm{Hg}$. Methylmercury is more toxic 256 than inorganic mercury (National Research Council, 2000), and metallothioneins protect cells 
257 from inorganic mercury but not $\mathrm{MeHg}$ (Wiener and Spry, 1996). Although supported, this 258 argument is speculative and more research should be conducted on the roles of $\mathrm{MeHg}$ and 259 inorganic mercury in liver toxicity.

260 Fish health, as suggested by condition factor, was related inversely to total mercury in 261 livers of Isle Royale northern pike (Fig. 3). Accordingly, fish with elevated levels of total 262 mercury in the liver generally had more lipofuscin granules and decreased lipid reserves in the

263 liver, and their overall condition was impaired. As is typical when MeHg limits a biological 264 response (Hammerschmidt et al., 2002; Drevnick and Sandheinrich, 2003; Drevnick et al., 265 2006b), there is little to no relationship between condition factor and liver total mercury 266 concentration at low concentrations, but as liver total mercury concentrations increase, the 267 maximum values for condition factor decrease (quantile regression, $97^{\text {th }}$ quantile, $P=0.040, n=$ 268 124). Northern pike with the highest concentrations of total mercury in livers and lowest 269 condition factors appeared emaciated. Rather than assigning causality to mercury exposure for 270 low condition factors, Cizdziel et al. (2003) hypothesized that emaciated fish undergoing 271 starvation deplete lipid reserves in the liver for energy, which concentrates mercury in the liver 272 because it is primarily bound to sulfhydryl groups in the remaining protein. This hypothesis is 273 plausible and may explain the decrease in lipid reserves we observed in northern pike livers. 274 However, the decrease in lipid reserves de Oliveira Ribeiro et al. (2002) observed was in 275 response to a single dose of dietary $\mathrm{MeHg}$ in arctic charr that were not emaciated or undergoing 276 starvation. Further, oxidative stress and the accumulation of lipid peroxidation products (i.e., 277 lipofuscin) would not be expected in livers from starvation alone (Abele et al., 2007). Our 278 research and that of others (Lockhart et al., 1972; Cizdziel et al., 2003) have documented an 279 inverse relationship between $\mathrm{MeHg}$ exposure and condition factor, but again more research is 280 required to assign causality.

\subsection{Implications}

Northern pike at Isle Royale are experiencing toxicity at concentrations of total mercury common for northern pike and other piscivorous fish elsewhere in North America. From linear 286 regressions of $\log _{10}$-transformed data (Sorensen et al., 1990), calculated concentrations of total mercury in skin-on fillets of legal-sized $(61 \mathrm{~cm})$ northern pike in the eight study lakes were 0.115 
(Siskiwit), 0.218 (Intermediate), 0.230 (Richie), 0.236 (Angleworm), 0.302 (Sargent), 0.324

289 (Wagejo), 0.337 (Eva), and 0.472 (Shesheeb) $\mu \mathrm{g} / \mathrm{g}$ wet wt. In comparison, Lockhart et al. (2005)

290 reported a mean total mercury concentration of $0.378 \mu \mathrm{g} / \mathrm{g}$ wet wt for fillets from 1,169 northern

291 pike (with a mean total length of $61 \mathrm{~cm}$ ) from northern Canada. Even greater, Kamman et al.

292 (2005) observed a mean total mercury concentration of $0.645 \mu \mathrm{g} / \mathrm{g}$ wet wt for fillets from 1,065

293 northern pike (also with a mean total length of $61 \mathrm{~cm}$ ) from eastern Canada and the northeastern

294 USA. In western North America, concentrations of total mercury in fillets of northern pike are

295 generally lower than elsewhere (Peterson et al., 2007), but still may exceed $1.5 \mu \mathrm{g} / \mathrm{g}$ wet wt

296 (Jewett et al., 2003). Further, in three major surveys (Kamman et al., 2005; Lockhart et al.,

297 2005; Peterson et al., 2007), other fish species consistently had higher fillet total mercury

298 concentrations than northern pike. Taken together, these comparisons indicate fish health may

299 be affected by concentrations of total mercury common in fish across North America.

$300 \quad$ Along with serving as an indicator of $\mathrm{MeHg}$ toxicity, liver color may be used to predict

301 concentrations of total mercury in fillets from northern pike at Isle Royale. Total mercury

302 concentrations in skin-on fillets were significantly correlated to the color of livers (step-wise

303 multiple regression, equation: skin-on fillet total mercury concentration $=0.081+[0.254 \mathrm{x}$ liver

304 color], $r^{2}=0.511, F_{1,122}=127.357, P<0.001$; Fig. 4). If the regression model is expanded to

305 include total length and wet weight, two variables commonly measured by people who catch and

306 eat fish, nearly $70 \%$ of the variation in total mercury concentrations in skin-on fillets is

307 accounted for (equation: skin-on fillet total mercury concentration $=-0.519+[0.184 \times$ liver

308 color $]+[0.015 \times$ total length $]+[-0.189 \times$ wet weight $\left.], r^{2}=0.690, F_{3,120}=89.023, P<0.001\right)$.

309 With careful development, this relationship could be used by anglers at Isle Royale to estimate

$310 \mathrm{MeHg}$ exposure as they decide lakeside whether to eat their catch.

312 4. Conclusion oxidative stress in livers of wild fish. We extend that observation by reporting liver toxicity

316 directly resulting from that oxidative stress. We previously linked oxidative stress to decreased

317 hormone production and, consequently, inhibited reproduction in fathead minnows (Pimephales 318 promelas) exposed to dietary MeHg (Drevnick et al., 2006b). Thus, mercury exposures 
encountered by northern pike and other fishes at Isle Royale and elsewhere in North America may cause liver toxicity as well as inhibit their ability to reproduce (Scheuhammer et al., 2007).

\section{Acknowledgements}

324 We thank the National Park Service for logistical support and many volunteers for field 325 sampling. Financial support was provided by the U.S. Environmental Protection Agency STAR 326 Graduate Fellowship Program to P.E.D. This manuscript is not subject to the U.S.

327 Environmental Protection Agency's peer review policy and therefore does not necessarily reflect 328 the views of the Agency and no official endorsement should be inferred.

\section{References}

Abele, D., Roecken, D., Graeve, M., Buck, B.H., 2007. Body growth, mitochondrial enzymatic capacities and aspects of the antioxidant system and redox balance under calorie restriction in young turbot (Scophthalmus maximus, L.). Aquacult. Res. 38, 467-477.

Bloom, N.S., 1992. On the chemical form of mercury in edible fish and marine invertebrate tissue. Can. J. Fish. Aquat. Sci. 49, 1010-1017.

Cade, B.S., Noon, B.R., 2003. A gentle introduction to quantile regression for ecologists. Front. Ecol. Environ. 1, 412-420.

Cizdziel, J., Hinners, T., Cross, C., Pollard, J., 2003. Distribution of mercury in tissues of five species of freshwater fish from Lake Mead, USA. J. Environ. Monitor. 5, 802-807.

de Oliveira Ribeiro, C.A., Belger, L., Pelletier, É., Rouleau, C., 2002. Histopathological evidence 
of inorganic mercury and methylmercury toxicity in the arctic charr (Salvelinus alpinus). Environ. Res. 90, 217-225.

Drevnick, P.E., Canfield, D.E., Gorski, P.R., Shinneman, A.L.C., Engstrom, D.R., Muir, D.C.G., Smith, G.R., Garrison, P.J., Cleckner, L.B., Hurley, J.P., Noble, R.B., Otter, R.R., Oris, J.T., 2007. Deposition and cycling of sulfur controls mercury accumulation in Isle Royale

Drevnick, P.E., Horgan, M.J., Oris, J.T., Kynard, B.E., 2006a. Ontogenetic dynamics of mercury accumulation in northwest Atlantic sea lamprey (Petromyzon marinus). Can. J. Fish. Aquat. Sci. 63, 1058-1066.

Drevnick, P.E., Sandheinrich, M.B., 2003. Effects of dietary methylmercury on reproductive endocrinology of fathead minnows. Environ. Sci. Technol. 37, 4390-4396.

Drevnick, P.E., Sandheinrich, M.B., Oris, J.T., 2006b. Increased ovarian follicular apoptosis in fathead minnows (Pimephales promelas) exposed to dietary methylmercury. Aquat. Toxicol. 79, 49-54.

Fitzgerald, W.F., Engstrom, D.R., Mason, R.P., Nater, E.A., 1998. The case of atmospheric mercury contamination in remote areas. Environ. Sci. Technol. 32, 1-7.

Friedmann, A.S., Costain, E.K., MacLatchy, D.L., Stansley, W., Washuta, E.J., 2002. Effect of mercury on general and reproductive health of largemouth bass (Micropterus salmoides) from three lakes in New Jersey. Ecotoxicol. Environ. Saf. 52, 117-122.

Goldstein, R.M., Brigham, M.E., Stauffer, J.C., 1996. Comparison of mercury concentrations in liver, muscle, whole bodies, and composites of fish from the Red River of the North. Can. J. Fish. Aquat. Sci. 53, 244-252.

Gonzalez, P., Dominique, Y., Massabuau, J.C., Boudou, A., Bourdineaud, J.P., 2005. Comparative effects of dietary methylmercury on gene expression in liver, skeletal muscle, and brain of the zebrafish (Danio rerio). Environ. Sci. Technol. 39, 3972-3980.

Gorski, P.R., Cleckner, L.B., Hurley, J.P., Sierszen, M.E., Armstrong, D.E., 2003. Factors affecting enhanced mercury bioaccumulation in inland lakes of Isle Royale National Park, USA. Sci. Total Environ. 304, 327-348.

Hall, B.D., Bodaly, R.A., Fudge, R.J.P., Rudd, J.W.M., Rosenburg, D.M., 1997. Food as the dominant pathway of methylmercury uptake by fish. Water Air Soil Pollut. 100, 13-24.

Hall, B.D., Rosenburg, D.M., Wiens, A.P., 1998. Methyl mercury in aquatic insects from an 
experimental reservoir. Can. J. Fish. Aquat. Sci. 55, 2036-2047.

Hammerschmidt, C.R., Fitzgerald, W.F., 2005. Methylmercury in mosquitoes related to atmospheric mercury deposition and contamination. Environ. Sci. Technol. 39, 30343039.

Hammerschmidt, C.R., Sandheinrich, M.B., Wiener, J.G., Rada, R.G., 2002. Effects of dietary methylmercury on reproduction of fathead minnows. Environ. Sci. Technol. 36, 877-883.

Hammerschmidt, C.R., Wiener, J.G., Frazier, B.E., Rada, R.G., 1999. Methylmercury content of eggs in yellow perch related to maternal exposure in four Wisconsin lakes. Environ. Sci. Technol. 33, 999-1003.

Hinck, J.E., Schmitt, C.J., Echols, K.R., May, T.W., Orazio, C.E., Tillitt, D.E., 2006. Environmental contaminants in fish and their associated risk to piscivorous wildlife in the Yukon River Basin, Alaska. Arch. Environ. Contam. Toxicol. 51, 661-672.

Holden, P.R., 2000. Toxic mechanisms mediated by gene expression. In: Roberts, R.A. (Ed.), Apoptosis in Toxicology. Taylor and Francis, London, pp. 187-211.

Hontela, A., Dumont, P., Duclos, D., Fortin, R., 1995. Endocrine and metabolic dysfunction in yellow perch, Perca flavescens, exposed to organic contaminants and heavy metals in the St. Lawrence River. Environ. Toxicol. Chem. 14, 725-731.

Jearld, A. Jr., 1983. Age determination. In: Nielsen, L.A., Johnson, D.L. (Eds.), Fisheries Techniques. American Fisheries Society, Bethesda, MD, pp. 310-324.

Jewett, S.C., Zhang, X., Naidu, A.S., Kelley, J.J., Dasher, D., Duffy, L.K., 2003. Comparison of mercury and methylmercury in northern pike and Arctic grayling from western Alaska rivers. Chemosphere 50, 383-392.

Kallemeyn, L.W., 2000. A Comparison of Fish Communities from 32 Inland Lakes in Isle Royale National Park, 1929 and 1995-1997. U.S. Geological Survey Biol. Sci. Rep. 2000-0004, Washington, DC.

Kamman, N.C., Burgess, N.M., Driscoll, C.T., Simonin, H.A., Goodale, W., Linehan, J., Estabrook, R., Hutcheson, M., Major, A., Scheuhammer, A.M., Scruton, D.A., 2005. Mercury in freshwater fish in northeast North America - a geographic perspective based on fish tissue monitoring databases. Ecotoxicology 14, 163-180.

Larose, C., Canuel, R., Lucotte, M., Di Giulio, R. T., 2007. Toxicological effects of methylmercury on walleye (Sander vitreus) and perch (Perca flavescens) from lakes of 
the boreal forest. Comp. Biochem. Phys. C, doi: 10.1016/j.cbpc.2007.09.002.

Lockhart, L.W., Stern, G.A., Low, G., Hendzel, M., Boila, G., Roach, P., Evans, M.S., Billeck, B.N., DeLaronde, J., Friesen, S., Kidd, K., Atkins, S., Muir, D.C.G., Stoddart, M., Stephens, G., Stephenson, S., Harbicht, S., Snowshoe, N., Grey, B., Thompson, S., DeGraff, N., 2005. A history of total mercury in edible muscle of fish from lakes in northern Canada. Sci. Total Environ. 351-352, 427-463.

Lockhart, L.W., Uthe, J.F., Kenney, A.R., Mehrle, P.M., 1972. Methylmercury in northern pike (Esox lucius): distribution, elimination, and some biochemical characteristics of contaminated fish. J. Fish. Res. Bd. Can. 29, 1519-1523.

Matta, M.B., Linse, J., Cairncross, C., Francendese, L., Kocan, R.M., 2001. Reproductive and transgenerational effects of methylmercury or aroclor 1268 on Fundulus heteroclitus. Environ. Toxicol. Chem. 20, 327-335.

Meinelt, T., Krüger, R., Pietrock, M., Osten, R., Steinberg, C., 1997. Mercury pollution and macrophage centres in pike (Esox lucius) tissues. Environ. Sci. Pollut. Res. 4, 32-36.

Michigan Department of Environmental Quality, 2005. Fish Contaminant Monitoring Program Online Database $<$ http://www.deq.state.mi.us/fcmp/>.

National Research Council, 2000. Toxicological Effects of Methylmercury. National Academy Press, Washington, DC.

Peterson, S.A., Van Sickle, J., Herlihy, A.T., Hughes, R.M., 2007. Mercury concentrations in fish from streams and rivers throughout the western United States. Environ. Sci. Technol. 41, 58-65.

Porta, E.A. (Ed.), 1989. Lipofuscin and Ceroid Pigments. Plenum Press, New York, NY.

Presnell, J.K., Schreibman, M.P., 1997. Humason's Animal Tissue Techniques. Johns Hopkins University Press, Baltimore, MD.

Raldúa, D., Díez, S., Bayona, J.M., Barceló, D., 2007. Mercury levels and liver pathology in feral fish living in the vicinity of a mercury cell chlor-alkali factory. Chemosphere 66, 1217-1225.

Scheuhammer, A.M., Meyer, M.W., Sandheinrich, M.B., Murray, M.W., 2007. Effects of environmental methylmercury on the health of wild birds, mammals, and fish. Ambio 36, 12-18.

Schlenk, D., Zhang, Y.S., Nix, J., 1995. Expression of hepatic metallothionein messenger RNA 
in feral and caged fish species correlates with muscle mercury levels. Ecotoxicol. Environ. Saf. 31, 282-286.

Schmitt, C.J., Dethloff, G.M. (Eds.), 2000. Biomonitoring of Environmental Status and Trends (BEST) Program: Selected Methods for Monitoring Chemical Contaminants and their Effects in Aquatic Ecosystems. U.S. Geological Survey Biol. Sci. Rep. 2000-0005, Columbia, MO.

Sorensen, J.A., Glass, G.E., Schmidt, K.W., Huber, J.K., Rapp, G.R., 1990. Airborne mercury deposition and watershed characteristics in relation to mercury concentrations in water, sediments, plankton, and fish of 80 northern Minnesota lakes. Environ. Sci. Technol. 24, 1716-1727.

Swackhamer, D.L., Hites, R.A., 1988. Occurrence and bioaccumulation of organochlorine compounds in fishes from Siskiwit Lake, Isle Royale, Lake Superior. Environ. Sci. Technol. 22, 543-548.

Tseng, C.M., Hammerschmidt, C.R., Fitzgerald, W.F., 2004. Determination of methylmercury in environmental matrixes by on-line flow injection and atomic fluorescence spectrometry. Anal. Chem. 76, 7131-7136.

U.S. Environmental Protection Agency, 1991. Methods for the Determination of Metals in Environmental Samples. U.S. Environmental Protection Agency Rep. 600/4-91-010, Washington, DC.

Webb, M.A.H., Feist, G.W., Fitzpatrick, M.S., Foster, E.P., Schreck, C.B., Plumlee, M., Wong, C., Gundersen, D.T., 2006. Mercury concentrations in gonad, liver, and muscle of white sturgeon Acipenser transmontanus in the lower Columbia River. Arch. Environ. Contam. Toxicol. 50, 443-451.

Wiener, J.G., Bodaly, R.A., Brown, S.S., Lucotte, M., Newman, M.C., Porcella, D.B., Reash, R.J., Swain, E.B., 2007. Monitoring and evaluating trends in methylmercury accumulation in aquatic biota. In: Harris, R., Krabbenhoft, D.P., Mason, R., Murray, M.W., Reash, R., Saltman, T. (Eds.), Ecosystem Responses to Mercury Contamination: Indicators of Change. CRC Press, Boca Raton, FL, pp. 88-122.

Wiener, J.G., Knights, B.C., Sandheinrich, M.B., Jeremiason, J.D., Brigham, M.E., Engstrom, D.R., Woodruff, L.G., Cannon, W.F., Balogh, S.J., 2006. Mercury in soils, lakes, and fish in Voyageurs National Park (Minnesota): importance of atmospheric deposition and 
ecosystem factors. Environ. Sci. Technol. 40, 6261-6268.

475 Wiener, J.G., Krabbenhoft, D.P., Heinz, G.H., Scheuhammer, A.M., 2003. Ecotoxicology of mercury. In: Hoffman, D.J., Rattner, B.A., Burton, Jr., G.A., Cairns, Jr., J. (Eds.), Handbook of Ecotoxicology, $2^{\text {nd }}$ ed. CRC Press, Boca Raton, FL, pp. 409-463.

478 Wiener, J.G., Spry, D.J., 1996. Toxicological significance of mercury in freshwater fish. In: Beyer, W.N., Heinz, G.H., Redmon-Norwood, A.W. (Eds.), Environmental Contaminants in Wildlife: Interpreting Tissue Concentrations. CRC Press, Boca Raton, FL, pp. 297339.

482 Woodruff, L.G., Cannon, W.F., Dicken, C.L., Bennett, J.P., Nicholson, S.W., 2003. Bedrock, 483 Soil, and Lichen Geochemistry from Isle Royale National Park, Michigan. U.S.

484 Geological Survey Open-File Rep. 03-276, Denver, CO.

485 Woshner, V.M., O’Hara, T.M., Eurell, J.A., Wallig, M.A., Bratton, G.R., Suydam, R.S., Beasley, 486 V.R., 2002. Distribution of inorganic mercury in liver and kidney of beluga and bowhead 487 whales through autometallgraphic development of light microscopic tissue sections.

488 Toxicol. Pathol. 30, 209-215. 
489 Table 1. Summary data for age, total length, wet weight, and concentrations of total mercury $490\left(\mathrm{Hg}_{\mathrm{T}}\right)$ in skin-on edible fillets and livers of northern pike collected from lakes at Isle Royale, 491 Michigan, 2004-2006. SD represents one standard deviation.

\begin{tabular}{|c|c|c|c|c|c|c|c|c|c|c|}
\hline \multirow[b]{2}{*}{ Lake } & \multirow[b]{2}{*}{$n$} & \multicolumn{3}{|c|}{ Fish Characteristics (means) } & \multicolumn{3}{|c|}{$\mathrm{Hg}_{\mathrm{T}}(\mu \mathrm{g} / \mathrm{g}$ wet wt) in edible fillet } & \multicolumn{3}{|c|}{$\mathrm{Hg}_{\mathrm{T}}(\mu \mathrm{g} / \mathrm{g}$ wet wt $)$ in liver } \\
\hline & & Age (y) & Length $(\mathrm{cm})$ & Weight (kg) & Mean & SD & Range & Mean & SD & Range \\
\hline Angleworm & 12 & 4.3 & 51.4 & 0.80 & 0.171 & 0.138 & $0.077-0.528$ & 0.392 & 0.859 & $0.058-3.074$ \\
\hline Eva & 12 & 5.2 & 52.5 & 0.81 & 0.262 & 0.115 & $0.133-0.463$ & 0.284 & 0.192 & $0.092-0.766$ \\
\hline Intermediate & 20 & 5.0 & 52.3 & 0.85 & 0.171 & 0.072 & $0.096-0.424$ & 0.181 & 0.224 & $0.061-1.107$ \\
\hline Richie & 16 & 4.9 & 56.0 & 0.97 & 0.200 & 0.073 & $0.114-0.346$ & 0.176 & 0.052 & $0.115-0.267$ \\
\hline Sargent & 20 & 5.7 & 55.4 & 1.01 & 0.242 & 0.139 & $0.114-0.622$ & 0.340 & 0.413 & $0.090-1.483$ \\
\hline Shesheeb & 14 & 5.4 & 55.0 & 0.90 & 0.299 & 0.119 & $0.142-0.471$ & 0.221 & 0.098 & 0.091-0.394 \\
\hline Siskiwit & 11 & 5.1 & 67.2 & 2.14 & 0.122 & 0.041 & $0.069-0.234$ & 0.087 & 0.029 & $0.048-0.121$ \\
\hline Wagejo & 19 & 5.0 & 52.7 & 0.82 & 0.242 & 0.127 & $0.101-0.582$ & 0.216 & 0.163 & $0.065-0.617$ \\
\hline
\end{tabular}

492 


\section{Figure Legends}

495 Fig. 1. Relationship between concentrations of total mercury $\left(\mathrm{Hg}_{\mathrm{T}}\right)$ in skin-on edible fillets and

496 livers of northern pike collected from lakes at Isle Royale, Michigan, 2004-2006. The dashed

497 line represents a 1:1 relationship between variables. Inset graph shows the relationship between

498 liver-to-fillet $\mathrm{Hg}_{\mathrm{T}}$ ratio and \% methylmercury $(\mathrm{MeHg})$ of $\mathrm{Hg}_{\mathrm{T}}$ in livers from ten of the northern

499 pike. The numbers inside the data points represent liver $\mathrm{Hg}_{\mathrm{T}}$ concentration. The trend line

500 represents the $99^{\text {th }}$ quantile.

502 Fig. 2. Mercury toxicity in livers of northern pike from Isle Royale, Michigan. Lightly-colored, 503 pink livers (A) had low total mercury concentrations and darkly-colored, red to brown livers (B)

504 had high total mercury concentrations. Lipofuscin was identified as the pigment in darkly-

505 colored livers, with light (C) and fluorescence (D) microscopy. Arrows indicate lipofuscin

506 granules. The mean proportion of grid squares (see materials and methods for explanation)

507 containing lipofuscin (E) explained $81 \%$ of the variation in liver color (least-squares regression, $\left.508 r^{2}=0.81, P=0.006, n=7\right)$.

510 Fig. 3. Relationship between total mercury $\left(\mathrm{Hg}_{\mathrm{T}}\right)$ concentration in livers and condition factor in

511 northern pike from lakes at Isle Royale, Michigan. The trend line represents the $97^{\text {th }}$ quantile.

513 Fig. 4. Relationship between liver color (as absorbance at $400 \mathrm{~nm}$ ) and total mercury $\left(\mathrm{Hg}_{\mathrm{T}}\right)$

514 concentration in skin-on edible fillets of northern pike from lakes at Isle Royale, Michigan. 
$515 \quad$ Figure 1

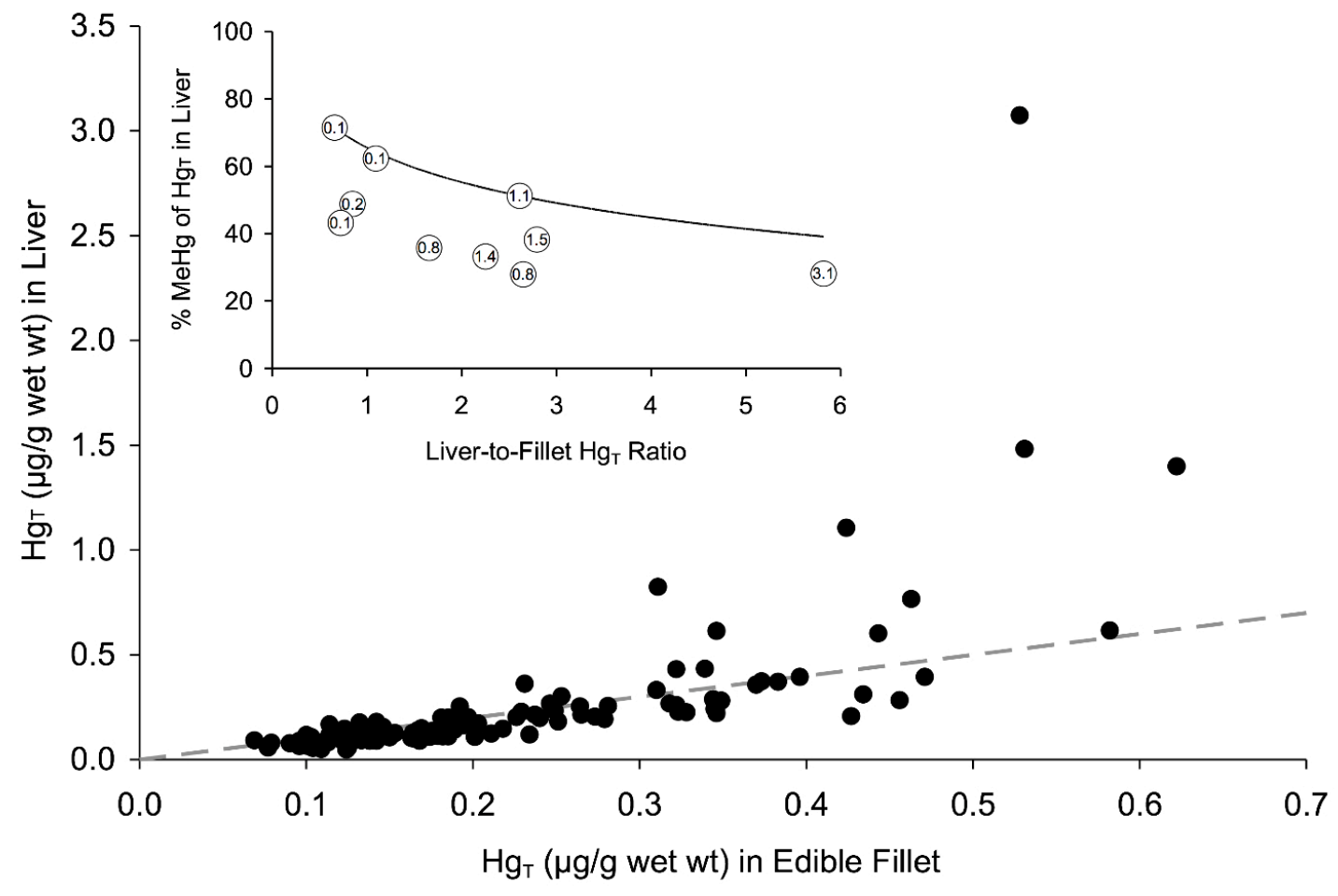

516 
517 Figure 2

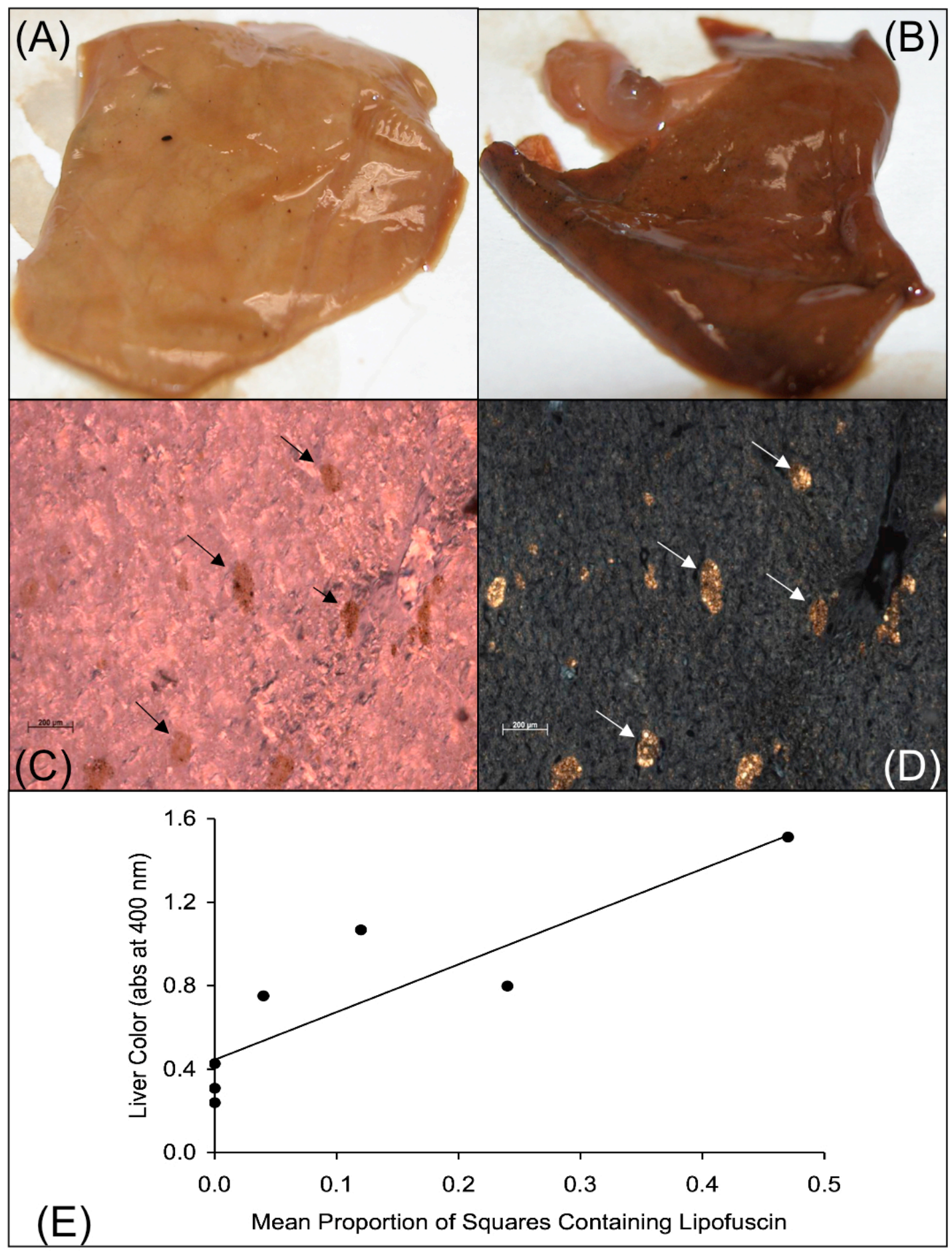


$519 \quad$ Figure 3

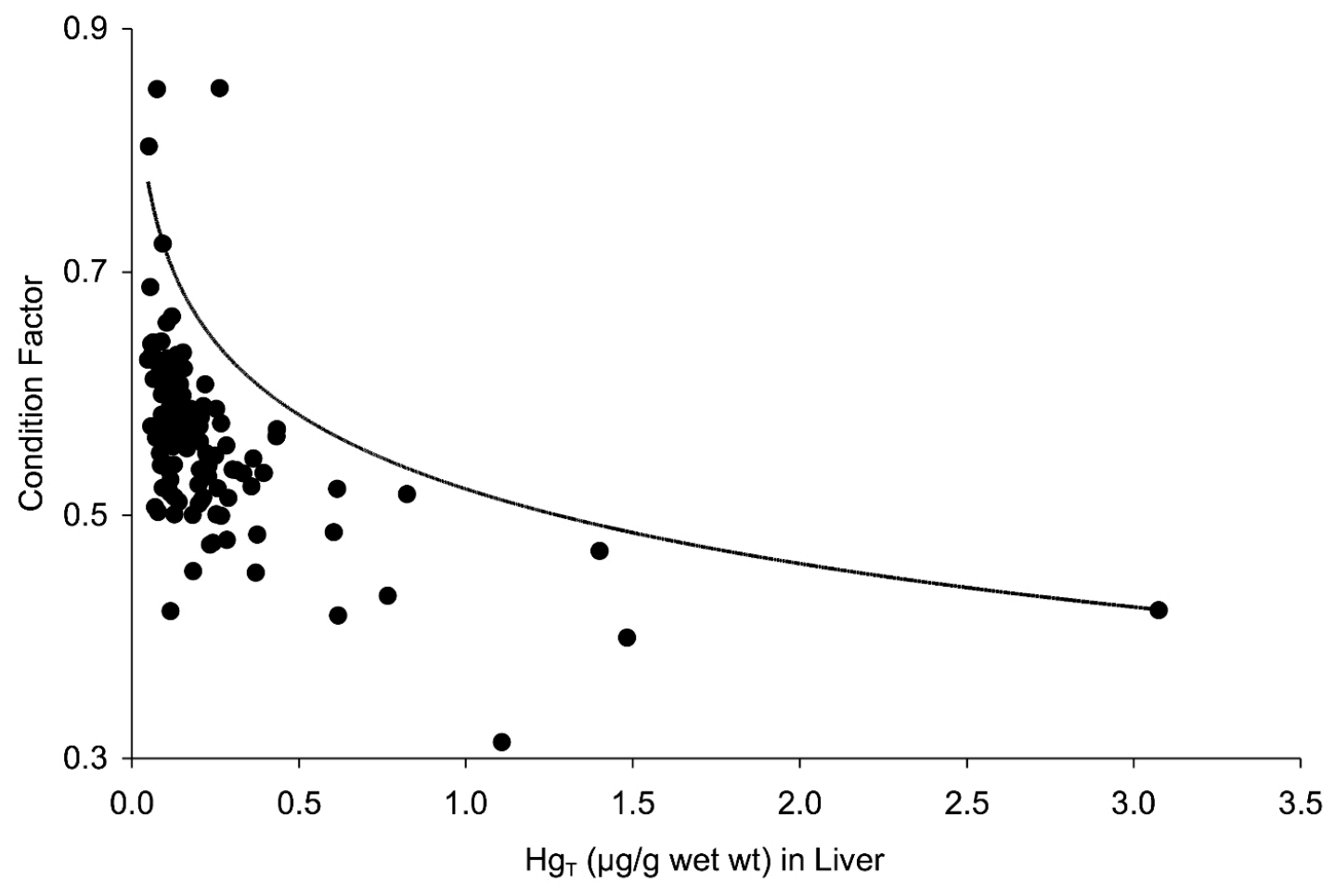


521 Figure 4

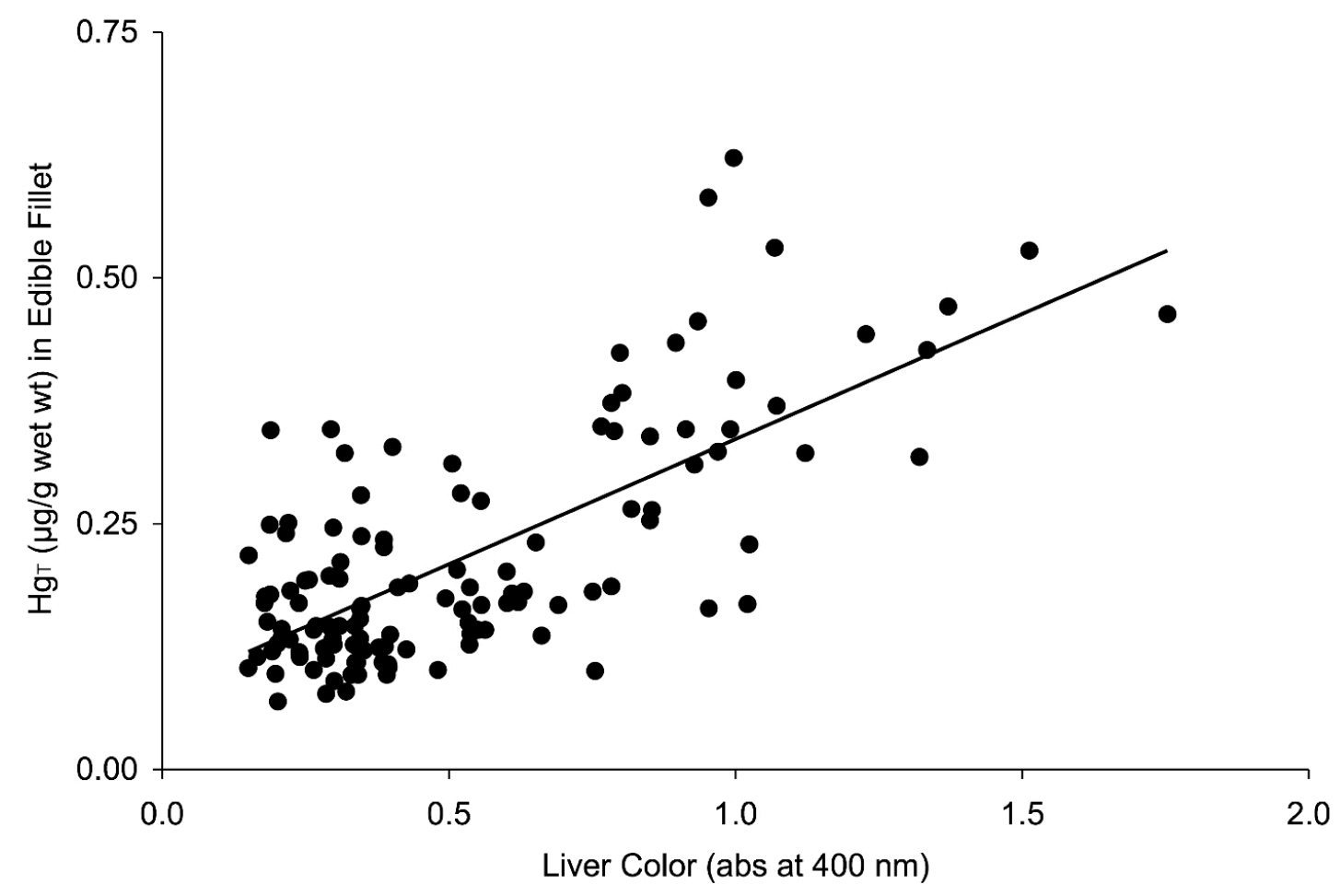

